\title{
Study on Genetic Diversity in Reference set of Chickpea Genotypes
}

\author{
L. Ramchander ${ }^{\text {* }}$, R. Sadhukhan ${ }^{1}$, P. Dinesh Kumar ${ }^{2}$, S. Dewanjee ${ }^{1}$, \\ S. K. Mukhopadyay ${ }^{3}$ and Rajib $\mathrm{Nath}^{3}$ \\ ${ }^{1}$ Department of Genetics and Plant Breeding, ${ }^{2}$ Department of Agricultural Statistics, \\ ${ }^{3}$ Department of Agronomy, Bidhan Chandra Krishi Vishwavidyalaya, \\ West Bengal, India \\ *Corresponding author
}

\section{A B S T R A C T}

\begin{tabular}{|l|}
\hline K e y w o r d s \\
$\begin{array}{l}\text { Chickpea, Genetic } \\
\text { diversity, Genetic } \\
\text { variability, Inter- } \\
\text { Intra cluster } \\
\text { distance }\end{array}$ \\
\hline Article Info \\
\hline $\begin{array}{l}\text { Accepted: } \\
\text { 05 February } 2020 \\
\text { Available Online: } \\
\text { 10 March } 2020\end{array}$ \\
\hline
\end{tabular}

To estimate the genetic diversity among the 104 chickpea genotypes, an experiment was carried out based on Augmented Randomized Complete Block Design with eight blocks in two locations during rabi seasons of 2015-2016 and 2016-2017. All the 104 chickpea genotypes were classified into 5 clusters. The inter-cluster distances were more than intracluster distances this indicates that a sufficient amount of genetic variability was present in the study material. Inter cluster $\mathrm{D}^{2}$ values ranged from 62.50 to 87.52 . Maximum inter cluster distance was between cluster III and IV (87.52) while minimum inter cluster distance (62.50) was observed between cluster I and II indicating presence of diversity in these clusters. The cluster II showed maximum intra cluster $\mathrm{D}^{2}$ value $(59.10)$. Among all the characters, number of pods per plant contributed the maximum $(29.69 \%)$ to the diversity by taking first rank in 1468 times out of 4945 combinations. Cluster III which consists of 5 genotypes showed maximum mean value for number of pods per plant, shoot phosphorus concentration and seed yield per plant may be of importance for yield characters. Diverse clusters namely, III and V consists of diverse parents hold good promise for superior hybrids for desirable characters and thereby creating greater possibilities of obtaining phosphorus acquisition efficient with high yielders

\section{Introduction}

Chickpea (Cicer arietinum L.) is the $3^{\text {rd }}$ largest produced food legume in the world after common bean and field pea and is widely grown in the semi-arid regions (Gaur et al., 2012). It is important pulse crop in India and contributing about $70 \%$ of the global chickpea production (FAOSTAT, 2012). It has excellent nutrition value in terms of human dietary protein. In addition to having high protein content (20-22\%) (McIntosh and Topping 2000; Charles et al., 2002). The genetic diversity analysis was more useful in to identify diverse genotypes from random population (Jing et al., 2010) 
and to estimate the efficient heterotic combinations before attempting crosses and hence saving resources and time (Halluer and Miranda, 1988). This information can helpful for transfer of useful genes from wild germplasm resources to the high yielding germplasm resource (Thompson et al., 1998). The purpose of the present study is to identify the genetic divergence among the chickpea genotypes for Seed yield and its attributing characters.

\section{Materials and Methods}

The present experiment was conducted during rabi season of 2015-16 and 2016-17 over two different locations viz. Regional Research Sub Station (RRSS) of Bidhan Chandra Krishi Viswavidyalaya, Sekhampur, Birbhum(Red and Lateritic Zone)and District Seed Farm, 'AB' block, Kalyani, Nadia (New Alluvial Zone), West Bengal, India with 104 chickpea genotypes including four check varieties viz., Anuradha, BG-256, KWR-108 and JG-14. These genotypes were collected from International Center for Agriculture Research in the Dry Areas (ICARDA), International Crops Research Institute for the Semi-Arid Tropics (ICRISAT) and All India Coordinated Research Project on Chickpea (AICRP on Chickpea), Directorate of Research, Bidhan Chandra Krishi Viswavidyalaya, Kalyani, Nadia, West Bengal, India. The details regarding the two experimental sites were presented in Table 1. In both the experimental sites recommended agronomical and plant protection practices were adopted for better crop growth. Each genotype was accommodated in a row with a length of $4 \mathrm{~m}$, keeping plant to plant distance of $10 \mathrm{~cm}$ and row to row distance of $30 \mathrm{~cm}$. Rice was the preceding crop at both the sites before chick pea sowing. The experiment was conducted in Augmented Randomized Complete Block Design (Federer, 1956) with eight blocks. Observations were recorded as per the DUS guidelines of chickpea, on the basis of five randomly selected plants in each genotype for various yield and yield attributing traits. The overall mean value was calculated from the two locations (Kalyani and Sekhampur) for two years (2015-16 and 2016-17) with augmented adjusted values. These mean values were used in diversity analysis. The statistical analysis was performed by using $\mathrm{R}$ software.

\section{Results and Discussion}

\section{Genetic divergence among the genotypes}

Genetic divergence plays an important role in analyzing the genetic distance among the genotypes selected as parents in breeding programme. Within a certain limit, hybridization between more divergent parents is expected to increase the level of heterosis and generate huge range of variability in segregating generations. The data collected on seed yield and other agro morphological characters from the genotypes of chickpea were subjected to multivariate analysis. The magnitude of values suggested that there was considerable variability in the material studied, which led to genetic diversity.

\section{Relative contribution of different characters towards genetic divergence}

The relative ranking of various character components to divergence $\mathrm{D}^{2}$ was furnished in Table 2. The result on character wise contribution towards total genetic divergence showed that no single character had a great contribution to total divergence.

Among all the characters, number of pods per plant contributed the maximum (29.69 per cent) to the diversity by taking first rank in 1468 times out of 4945 combinations, which was followed by days to first flowering (16.91 per cent with 836 times ranked first). The 
other characters viz., hundred seed weight, days to 50 per cent flowering, plant height, plant biomass, pod bearing height, days to maturity, number of seeds per pod, seed yield per plant, number of secondary branches, shoot phosphorus concentration, harvest index and number of primary branches per plant contributed 16.89, 11.00, 6.01, 5.84, 5.10, $3.42,3.05,0.79,0.73,0.34,0.18$ and 0.06 per cent respectively to the genetic divergence in decreasing order. Number of pods per plant, days to first flowering, hundred seed weight and days to 50 per cent flowering contributed maximum towards diversity. The characters with maximum contribution towards diversity should be given due consideration for chickpea crop improvement. These results confirmed with Pahre et al., (2014) and Kuldeep et al., (2015). They reported that number of pods per plant and 100 seed weight contributed maximum towards genetic diversity. Thakur et al., (2018) noticed that days to $50 \%$ flowering followed by 100 seed weight, total number of seeds per plant, plant height and pods per plant. Parashi et al., (2013) reported those days to $50 \%$ flowering and number of seeds per plant contributed maximum towards genetic diversity.

\section{Grouping of genotypes into various clusters}

In the present study 104 chickpea genotypes were grouped into five clusters using the Tocher's method with the criterion that the intra-cluster average $\mathrm{D}^{2}$ values should be less than the inter-cluster $\mathrm{D}^{2}$ values. The distribution of genotypes into five clusters is presented in Table 3. Among all the clusters, cluster II was the largest containing 74 genotypes followed by cluster I and cluster V with 9genotypes, cluster III with 5 genotypes and cluster IV with 7 genotypes.

\section{Intra and inter- cluster $\mathrm{D}^{2}$ values}

The average intra and inter-cluster $\mathrm{D}^{2}$ values estimated as per the procedure given by Singh and Chowdhary (1977) are presented in the Table 4. The maximum inter-cluster distance (87.52) was found between cluster III and IV followed by that between II and V (74.54). The minimum inter-cluster distance was observed between cluster I and II (62.50). The intra-cluster distance ranged from 39.48 (cluster-I) to 59.10 (cluster-II). In general, intra-cluster distances were lower than the inter-cluster distances.

Thus, the genotypes included within a cluster tended to diverse less from each other. The genotypes belonging to the clusters separated by high genetic distance could be used in hybridization programme for obtaining a wide spectrum of variation among the segregants (Arunachalam, 1981). Choice of the particular cluster and selection of particular genotype from selected cluster are the two important points to be considered before initiating the crossing programme. Therefore, in the present investigation, based upon high phosphorus acquisition efficiency and large inter-cluster distances, it is advisable to attempt crossing of the genotypes from clusters III and IV, which may lead to produce broad spectrum of favorable genetic variability for phosphorus uptake efficiency improvement in chickpea.

\section{Cluster means of various characters}

Cluster means indicate average performance of all varieties clubbed in a cluster. The relative importance of yield components contributing towards divergence can be judged by comparing the group means of 15 characters. The clusters mean values for all the 15 characters are presented in Table 5. Wide ranges of mean values among the clusters were recorded for different traits. The cluster I manifested highest mean values for number of seeds per pod (1.25) and lowest mean value for pod bearing height (24.83 $\mathrm{cm})$. 
Table.1 Description regarding the experiment sites

\begin{tabular}{|c|c|c|c|c|c|c|c|}
\hline Location & $\begin{array}{c}\text { Latitude \& } \\
\text { longitude }\end{array}$ & $\begin{array}{c}\text { Elevation } \\
(\mathbf{m s l})\end{array}$ & $\mathbf{p H}$ & $\begin{array}{c}\text { Org C } \\
(\mathbf{\%})\end{array}$ & $\begin{array}{c}\mathbf{N} \\
\left(\mathbf{K g ~ h a}^{-\mathbf{1}}\right)\end{array}$ & $\begin{array}{c}\mathbf{P} \\
\left(\mathbf{K g ~ h a}^{-\mathbf{1}}\right)\end{array}$ & $\begin{array}{c}\mathbf{K} \\
\left(\mathbf{K g ~ h a}^{-\mathbf{1}}\right)\end{array}$ \\
\hline $\begin{array}{c}\text { RRSS, BCKV, } \\
\text { Sekhampur, } \\
\text { Birbhum, West } \\
\text { Bengal, India }\end{array}$ & $\begin{array}{c}23^{0} 55^{\prime} \mathrm{N} \& \\
87^{0} 32^{\prime} \mathrm{E}\end{array}$ & 11.5 & 5.38 & 0.49 & 176.5 & 9.4 & 188.1 \\
\hline $\begin{array}{c}\text { District Seed Farm, } \\
\text { 'AB' block, BCKV, } \\
\text { Kalyani, Nadia, } \\
\text { West Bengal, India }\end{array}$ & $\begin{array}{c}23^{0} 50^{\prime} \mathrm{N} \& \\
89^{0} 00^{\prime} \mathrm{E}\end{array}$ & 9.75 & 7.56 & 0.55 & 198.7 & 13.5 & 115.3 \\
\hline
\end{tabular}

Table.2 Relative contribution of different characters towards genetic divergence

\begin{tabular}{|r|l|c|c|}
\hline S.No & $\begin{array}{l}\text { Character } \\
\text { Name }\end{array}$ & $\begin{array}{l}\text { Number of times ranked } \\
\text { first }\end{array}$ & $\begin{array}{l}\text { Per cent contribution towards } \\
\text { divergence }\end{array}$ \\
\hline $\mathbf{1}$ & DFF & 836 & 16.91 \\
\hline $\mathbf{2}$ & D50F & 297 & 6.01 \\
\hline $\mathbf{3}$ & DM & 169 & 3.42 \\
\hline $\mathbf{4}$ & PH & 544 & 11.00 \\
\hline $\mathbf{5}$ & PBH & 252 & 5.10 \\
\hline $\mathbf{6}$ & NPB & 3 & 0.06 \\
\hline $\mathbf{7}$ & NSB & 36 & 0.73 \\
\hline $\mathbf{8}$ & NPP & 1468 & 29.69 \\
\hline $\mathbf{9}$ & NSP & 151 & 3.05 \\
\hline $\mathbf{1 0}$ & HSW (g) & 835 & 16.89 \\
\hline $\mathbf{1 1}$ & PB (g) & 289 & 5.84 \\
\hline $\mathbf{1 2}$ & HI & 9 & 0.18 \\
\hline $\mathbf{1 3}$ & P (\%) & 17 & 0.34 \\
\hline $\mathbf{1 4}$ & SY/Plant $(\mathrm{g})$ & 39 & 0.79 \\
\hline & Total & 4945 & \\
\hline
\end{tabular}

DFF- Days to first flowering, D50F- Days to $50 \%$ flowering, DM - Days to maturity, PH- Plant height (cm), PBHPod bearing height $(\mathrm{cm})$,NPB- Number of primary branches per plant, NSB- Number of secondary branches per plant, NPP- Number of pods per plant, NSP- Number of seeds per pod,HSW -Hundred seed weight (g),PB - Plant biomass (g), HI-Harvest index, P- Shoot phosphorus concentration (\%) and SYP- Seed yield per plant (g). 
Table.3 Distribution of chickpea genotypes into different clusters (Tocher's method)

\begin{tabular}{|c|c|c|}
\hline $\begin{array}{l}\text { Cluster } \\
\text { No. }\end{array}$ & $\begin{array}{l}\text { No of } \\
\text { Genotypes } \\
\text { in Cluster }\end{array}$ & Name of the Genotypes \\
\hline I & 9 & $\begin{array}{l}\text { AGBL-110, AGBL-122, AGBL-160, GJG-0919, 24001-4-3, ICCV- } \\
\text { 13102, ICCV-13107, GG-1 and Vihar }\end{array}$ \\
\hline II & 74 & $\begin{array}{l}\text { AGBL-134, AGBL-146, AGBL-158, AGBL-172, GJG-0814, GJG- } \\
\text { 0904, GAG-1107, GAG-1111, GJG-1304, GJG-1311, Anuradha, } \\
\text { 24002-4-3, 24003-1-1, 24003-2-1, 24004-3-1, 24005-3-1, 24006-2-1, } \\
\text { 24007-5-1, 24015-2-1, 24015-4-1, 24017-1-124017-2-1, 24018-2-1, } \\
\text { 24031-1-1, 24031-3-1, 24032-2-1, 24034-4-1 24042-1-1, 24042-5-1, } \\
\text { 24043-4-1, IPC-2010-25, IPC-2010-37, IPC-2008-89, IPC-2011-69, } \\
\text { IPC-2011-141, IPC-2011-64, IPC-2011-123, IPC-2010-94, KWR- } \\
\text { 108,FLIP-07-255C, FLIP-07-249C, FLIP-07-176C, ICC-8621, ICC- } \\
\text { 4958, ICC-15618, ICC-16207, ICC-3325, ICC-15868, ICC-1098, } \\
\text { ICCV-13103, ICCV-13104, ICCV-13105, ICCV-13106, ICCV-1311, } \\
\text { ICCV-13118, ICCV-13305, ICCV-13306, ICCV-13307, ICCV } \\
\text { 13308, ICCV-13309, ICCV-13311, ICCV-13312, ICCV-13314, } \\
\text { ICCV-13316, ICCV-13317, ICCV-14103, ICCV-14118, JG-14, JG- } \\
\text { 16, GG-4, BG-256, RSG-888, DCP-92-3 and JG-11 }\end{array}$ \\
\hline III & 5 & AGBL-184, ICC-7441, ICCV-13101, ICCV-13318 and ICCV-14112 \\
\hline IV & 7 & $\begin{array}{l}\text { GJG-1211, IPC-2010-219, FLIP-07-36C, ICCV-13109, ICCV-13116, } \\
\text { ICCV-14107, ICCV-14108 }\end{array}$ \\
\hline $\mathbf{V}$ & 9 & $\begin{array}{l}\text { IPC-2011-70, FLIP-07-218C, FLIP-06-40C, FLIP-07-266C, FLIP-01- } \\
\text { 29C, FLIP-07-127C, FLIP-07-3C, ICCV-13117 and ICCV-14106 }\end{array}$ \\
\hline
\end{tabular}

Table.4 Intra and inter-cluster distances for quantitative characters using Tocher's method in chickpea

\begin{tabular}{|l|c|c|c|c|c|}
\hline Cluster No. & I & II & III & IV & V \\
\hline I & $\mathbf{3 9 . 4 8}$ & 62.50 & 63.47 & 66.24 & 68.52 \\
\hline II & & $\mathbf{5 9 . 1 0}$ & 70.18 & 68.49 & 74.54 \\
\hline III & & & $\mathbf{4 7 . 8 9}$ & 87.52 & 71.48 \\
\hline IV & & & & $\mathbf{5 7 . 9 4}$ & 68.06 \\
\hline V & & & & & $\mathbf{5 4 . 0 9}$ \\
\hline
\end{tabular}


Table.5 Mean seed yield per plant and other agro morphological traits in various clusters of chickpea (Tocher' method)

\begin{tabular}{|l|l|l|l|l|l|l|l|l|l|l|l|l|l|l|l|}
\hline Cluster & DFF & D50F & DM & PH & PBH & NPB & NSB & NPP & NSP & HSW & PB & HI & P & SYP & SYH \\
\hline I & 69.45 & 77.61 & 126.38 & 56.83 & 24.83 & 2.82 & 7.67 & 27.97 & 1.25 & 23.35 & 24.59 & 0.21 & 0.24 & 6.54 & 1.53 \\
\hline II & 65.28 & 75.92 & 125.30 & 55.01 & 25.32 & 2.61 & 6.78 & 30.51 & 1.20 & 21.71 & 20.95 & 0.22 & 0.23 & 5.91 & 1.44 \\
\hline III & 66.42 & 80.55 & 127.16 & 56.43 & 25.83 & 3.08 & 8.40 & 32.00 & 1.21 & 24.93 & 22.75 & 0.25 & 0.27 & 8.22 & 1.76 \\
\hline IV & 65.73 & 77.42 & 125.08 & 65.84 & 33.90 & 2.52 & 7.03 & 29.48 & 1.07 & 22.13 & 26.05 & 0.16 & 0.24 & 4.66 & 1.00 \\
\hline V & 77.19 & 86.81 & 131.28 & 69.89 & 35.04 & 2.60 & 6.55 & 26.15 & 1.09 & 27.78 & 21.84 & 0.19 & 0.26 & 5.46 & 1.28 \\
\hline
\end{tabular}

DFF- Days to first flowering, D50F- Days to $50 \%$ flowering, DM - Days to maturity, PH- Plant height $(\mathrm{cm})$, PBH-Pod bearing height $(\mathrm{cm}), \mathrm{NPB}-$ Number of primary branches per plant, NSBNumber of secondary branches per plant, NPP- Number of pods per plant, NSP- Number of seeds per pod, HSW -Hundred seed weight (g),PB - Plant biomass (g), HI-Harvest index, PShoot phosphorus concentration (\%), SYP- Seed yield per plant (g) and SYH- Seed yield per hectare $(\mathrm{t})$.

The cluster III showed highest mean values for number of primary branches per plant (3.08), number of secondary branches per plant (8.40), number of pods per plant (32.00), harvest index (0.25), shoot phosphorus concentration ( 0.27 per cent), seed yield per plant $(8.22 \mathrm{~g})$ and seed yield per hectare $(1.76 \mathrm{t})$. The cluster IV had highest cluster mean value for plant biomass $(26.05 \mathrm{~g})$. The cluster $\mathrm{V}$ exhibited highest mean value for days to first flowering (77.19), days to 50 per cent flowering (86.81), days to maturity (131.28), plant height $(69.89 \mathrm{~cm})$, pod bearing height (35.04) and hundred seed weight $(27.78 \mathrm{~g})$.

The cluster II showed lowest mean value for days to first flowering (65.28), days to 50 per cent flowering (75.92), plant height (55.01 $\mathrm{cm}$ ), pod bearing height (25.32), hundred seed weight $(21.71 \mathrm{~g})$ and shoot phosphorus concentration ( 0.23 per cent).Therefore, intercrossing of such genotypes involved in these clusters would be useful for generating variability for the respective characters, and their rational improvement for increasing the seed yield. Malik et al., (2014) reported that 11 genotypes with higher mean value for hundred seed weight grouped into a single cluster and a study under taken by Zali et al., (2011) using 17 chickpea genotypes obtained three clusters in which genotypes with maximum plant height, more number of secondary branches, seeds per plant, pods per plant and in turn resulted in higher seed yield formed a major cluster.

The clusters III and V were found superior for one or more characters. Therefore, it is proposed to arrange a multiple crossing programme involving genotypesfrom these clusters to isolate superior segregants in advanced generations with high genetic yield potential and other desirable characters in chickpea. Cluster III and cluster V consists of diverse parents hold good promise for superior hybrids for desirable characters and thereby creating greater chances of obtaining phosphorus acquisition efficient with high yielders. In the present study inter-cluster distances were more than intra-cluster 
distances indicating that sufficient amount of genetic diversity existed among the genotypes.

\section{Acknowledgement}

Authors are thankful to Bidhan Chandra Krishi Vishwa Vidyalaya, Mohanpur, West Bengal, India, International Center for Agriculture Research in the Dry Areas (ICARDA), International Crops Research Institute for the Semi-Arid Tropics (ICRISAT) and All India Coordinated Research Project on Chickpea (AICRP on Chickpea), Directorate of Research, Bidhan Chandra Krishi Viswavidyalaya, Kalyani, Nadia, West Bengal, India.

\section{References}

Arunachalam V. (1981). Genetic distance in plant breeding. Indian Journal of Genetics, 41(2):226-236.

Charles, M.T., Dominique, R., Kumar, J. and Dangi, O.P. (2002). A preliminary study of the functional properties of chickpea leaves. In: Annual Meeting of the Canadian Society of Food and Nutrition, Edmonton, Alberta, Canada 89-96.

Gaur, P.M., Jukanti A.K., Varshney, R.K. (2012). Impact of genomic technologies on chickpea breeding strategies. Agronomy, 2: 199-221. doi:10.3390/agronomy2030199

Halluer, A.R. and Miranda, J.B. (1988). Quantitative Genetics in Maize Breeding, second ed., Iowa State University Press, Ames, IA, USA, 1988.

Jing, R., Vershinin, A., Grzebyta, J., Shaw, P., Smýkal, P., Marshall, D., Ambose, M.J., Ellis, T.N. and Flavell, A.J. (2018). The genetic diversity and evolution of field pea studied by high throughput retrotransposon-based insertion polymorphism (RBIP) marker analysis, BMC Evolutionary Biology,
10:1-20.

Kuldeep, R., Pandey, S., Babbar, A. and Prakash, V. (2015). Genetic diversity analysis in Chickpea grown under heat stress conditions of Madhya Pradesh. Electronic Journal of Plant Breeding, 6(4): 962-971.

Malik, S.R., Shabbir, G., Zubur, M., Iqbal, S.M. and Ali. A. (2014). Genetic diversity analysis of morpho-genetic traits in desi chickpea (Cicer arietinum L.). International Journal of Agriculture and Biology, 16(5): 956-960.

McIntosh, G. H. and Topping, D. L. (2000). Food legumes in human nutrition. In 'Linking Research and Marketing Opportunities for Pulses in the 21st Century' (Eds R. Knight). 655-666. (Kluwer Academic Publishers, Dordrecht, The Netherlands).

Parashi, V. S., Lad, T. B., Mhase, L. B., Kute, N. S. and Sonawane, C. J. (2013). Genetic diversities studies in Chickpea (Cicer arietinum L.). Bioinfolet. 10(1B): 337-341.

Parhe, S.D., Harer, P.N. and Nagawade, D.N. (2014). Investigation of genetic divergence in chickpea (Cicer arietinum L.) genotypes. The Bioscan. 9(2): 879882.

Thakur, N. R., Toprope, V. N. and Koppuravuri S. P. (2018). Genetic Diversity Analysis in Chickpea (Cicer arietinum L.). International Journal of Current Microbiology and Applied Sciences, 6: 904-910.

Thompson, J.A., Nelson, R.L. and Vodkin, L.O. (1998). Identification of diverse soybean germplasm using RAPD markers. Crop Science, 38:1348-1355.

Zali, H., Farshadfar, F. and Sabaghpour, S.H. (2011). Genetic variability and interrelationships among agronomic traits in chickpea (Cicer arietinum L.) genotypes. Crop Breeding Journal, 1(2): 127-132. 


\section{How to cite this article:}

Ramchander. L, R. Sadhukhan, P. Dinesh Kumar, S. Dewanjee, S. K. Mukhopadyay and Rajib Nath. 2020. Study on Genetic Diversity in Reference set of Chickpea Genotypes. Int.J.Curr.Microbiol.App.Sci. 9(03): 396-403. doi: https://doi.org/10.20546/ijcmas.2020.903.047 